\title{
(Un-)shackling the University in the City
}

\begin{tabular}{|c|c|}
\hline \multicolumn{2}{|c|}{$\begin{array}{l}\text { Author: } \\
\text { Ulrike Kistner }\end{array}$} \\
\hline \multicolumn{2}{|c|}{$\begin{array}{l}\text { Affiliation: } \\
{ }^{1} \text { Department of Philosophy, } \\
\text { Faculty of Humanities, } \\
\text { University of Pretoria, } \\
\text { South Africa }\end{array}$} \\
\hline \multicolumn{2}{|c|}{$\begin{array}{l}\text { Note: } \\
\text { Panel on 'Contestation and } \\
\text { Dissensus' (14 August 2014) } \\
\text { of the 'Feast of the Clowns', } \\
\text { University of Pretoria, 11-16 } \\
\text { August 2014: 'The clown, } \\
\text { the university, the city: (un) } \\
\text { shackling liaisons'. }\end{array}$} \\
\hline \multicolumn{2}{|c|}{$\begin{array}{l}\text { Correspondence to: } \\
\text { Ulrike Kistner }\end{array}$} \\
\hline \multicolumn{2}{|c|}{$\begin{array}{l}\text { Email: } \\
\text { ulrike.kistner@up.ac.za }\end{array}$} \\
\hline \multicolumn{2}{|c|}{$\begin{array}{l}\text { Postal address: } \\
\text { Private Bag X20, Hatfield } \\
\text { 0028, Pretoria, South Africa }\end{array}$} \\
\hline \multicolumn{2}{|c|}{$\begin{array}{l}\text { Dates: } \\
\text { Received: } 02 \text { July } 2015 \\
\text { Accepted: } 15 \text { Aug. } 2015 \\
\text { Published: } 16 \text { Nov. } 2015\end{array}$} \\
\hline \multicolumn{2}{|c|}{$\begin{array}{l}\text { How to cite this article: } \\
\text { Kistner, U., 2015, '(Un-) } \\
\text { shackling the University in } \\
\text { the City', HTS Teologiese } \\
\text { Studies/Theological Studies } \\
71(3) \text {, Art. \#3101, } 14 \text { pages. } \\
\text { http://dx.doi.org/10.4102/ } \\
\text { hts.v71i3.3101 }\end{array}$} \\
\hline \multicolumn{2}{|c|}{$\begin{array}{l}\text { Copyright: } \\
\text { (C) 2015. The Authors. } \\
\text { Licensee: AOSIS } \\
\text { OpenJournals. This work is } \\
\text { licensed under the Creative } \\
\text { Commons Attribution } \\
\text { License. }\end{array}$} \\
\hline \multicolumn{2}{|l|}{ Read online: } \\
\hline 口idipla & $\begin{array}{l}\text { Scan this QR } \\
\text { code with your } \\
\text { smart phone or } \\
\text { mobile device } \\
\text { to read online. }\end{array}$ \\
\hline
\end{tabular}

This article examines the relation between the University of Pretoria and the City of Tshwane, outlining seven different kinds of relation as they have taken shape historically. The first type relation between the University and the City presented here, establishes correspondences in public architecture at the height of apartheid modernity, between structures marking and shaping political convergences. The second type of relation is premised on the walling in and fencing off of the University from the City; the Metro musings exhibition inaugurating the 'Capital Cities' project looks across the divides thus cemented, from within the confines of the University. The third type of relation is that of 'Community Engagement' culminating in the annual Mandela Day activities, impelled by ideas on the Developmental State featuring in the National Development Plan. In the fourth type of relation, corporate models of municipal governance find common cause with the corporate management styles of the University, expressed in corporate partnerships combining a 'University of Excellence' with 'the African City of Excellence'. The strategies envisaged for social intervention emerging from this 'partnership' form a sixth type of relation between the University and the City. In the process of pitting property and law against poverty and lawlessness, new civic challenges are emerging for transformative constitutionalism and for the University. In both arenas, this article concludes, what is at stake is a seventh type of relation between the University and the City - outside of the 'legal'-'illegal' distinction. For the University, in particular, this would entail a productive idea of 'dissensus'.

\section{Introduction}

The title 'The University and the City' is not a remarkably original one. In fact, it has severally been taken. ${ }^{1}$ We are not the first to think about the relation between the University and the City. Still, I would like to keep this title, as it can accommodate a range of prepositions and prepositional phrases that give a more specific character to the relation between the University and the City, such as 'The University in, of, above, apart from, extending out to, shaking hands with, divided from, engaging with the City.' But before outlining the multiplicity of relationships encapsulated in these prepositions - of which I will investigate seven kinds more closely here - I would need to point out that even in Pretoria, there are many who have considered the relationship between 'the University and the City'. So for the moment, I will relinquish any claim to originality, and consider some of our forerunners' visions, to then engage with our contemporaries' perspectives, and finally, to visualise a difference.

\section{The shape, and shaping, of the University in the City}

Some of their visions have taken shape in the built environment - which is what I would like to consider as the first kind of relation between the University and the City.

Coming onto campus from the City, we are faced with a sight shown in Figure 1.

Inside these walls, there's much continuity in evidence, an unbroken string of a tradition, in which one eeufees - that of the Groot Trek of 1838 marked with the spoor of the oxwagon in 1938 - blends into another - that of 2008, marking the centenary of the founding of the Transvaal University College in 1908 (see Figure 2 and Figure 3).

The design for the Merensky Library (1937-1938) offered its architect, Gerhard Moerdyk, a practice run for its big brother on Monument Hill (1937-1949) (Figure 4 and Figure 5).

1.See for example, Goddard and Vallance (2013); also Bender (1991); also the bi-annual conference series 'The University and the City' organised jointly by the Goethe University of Frankfurt a.M. and the University of Toronto, see http://www.university-and-city.com/ 


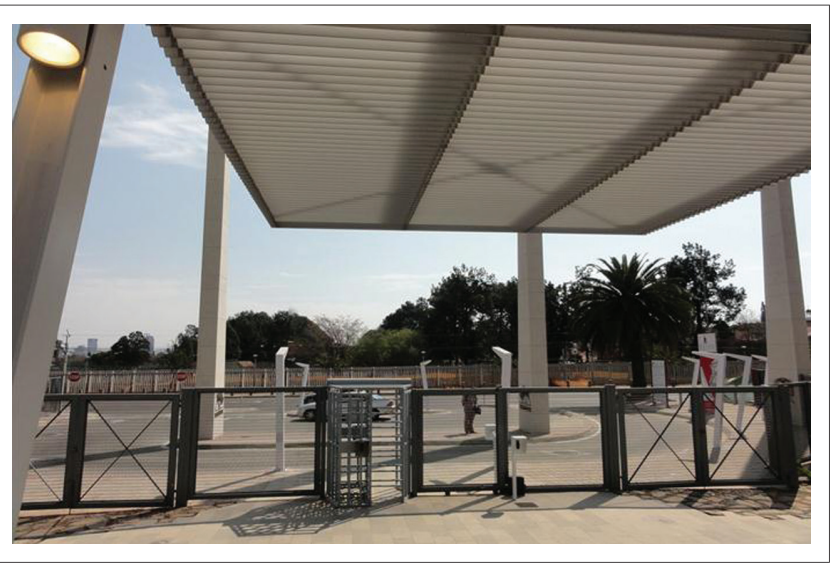

Source: Photo taken by author

FIGURE 1: University of Pretoria - gated entrance on University Road: 'The doors of learning and culture shall be locked.'

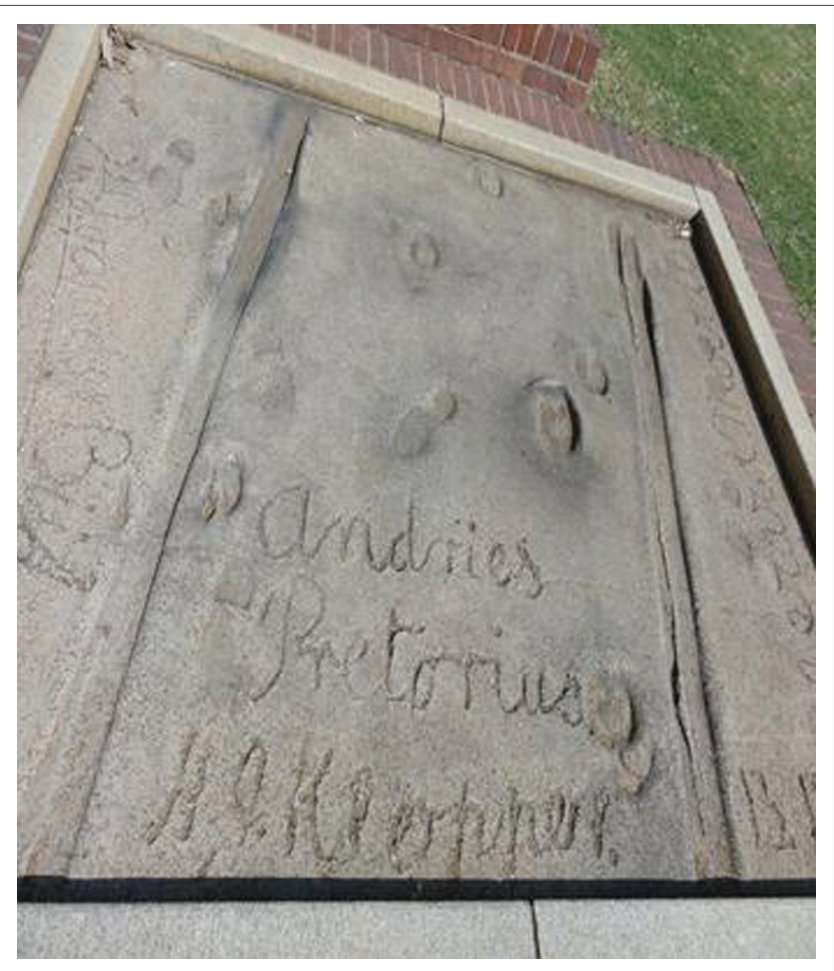

Source: Photo taken by author

FIGURE 2: Eeufees blues 1: Wagon tracks of the Groot Trek eeufees, University of Pretoria, 1938, now without wagon.

But there is also a groot skeuring - that of apartheid modernity - in the massive landmark buildings towering over earlier buildings fitting in with pre-existing traditions (Figure 6).

There's much that's built with Sand, Rock, and Broederbond, resonating with other buildings in and around the city of the same time period - (e.g. the Pelindaba uranium enrichment facility also commissioned to Brian Sandrock and Alewyn Burger in 1960) (Figure 7 and Figure 8).

Brian Sandrock's architectural oeuvre provides the most comprehensive record of the architecture of apartheid modernity. He started making his career in 1951, and was

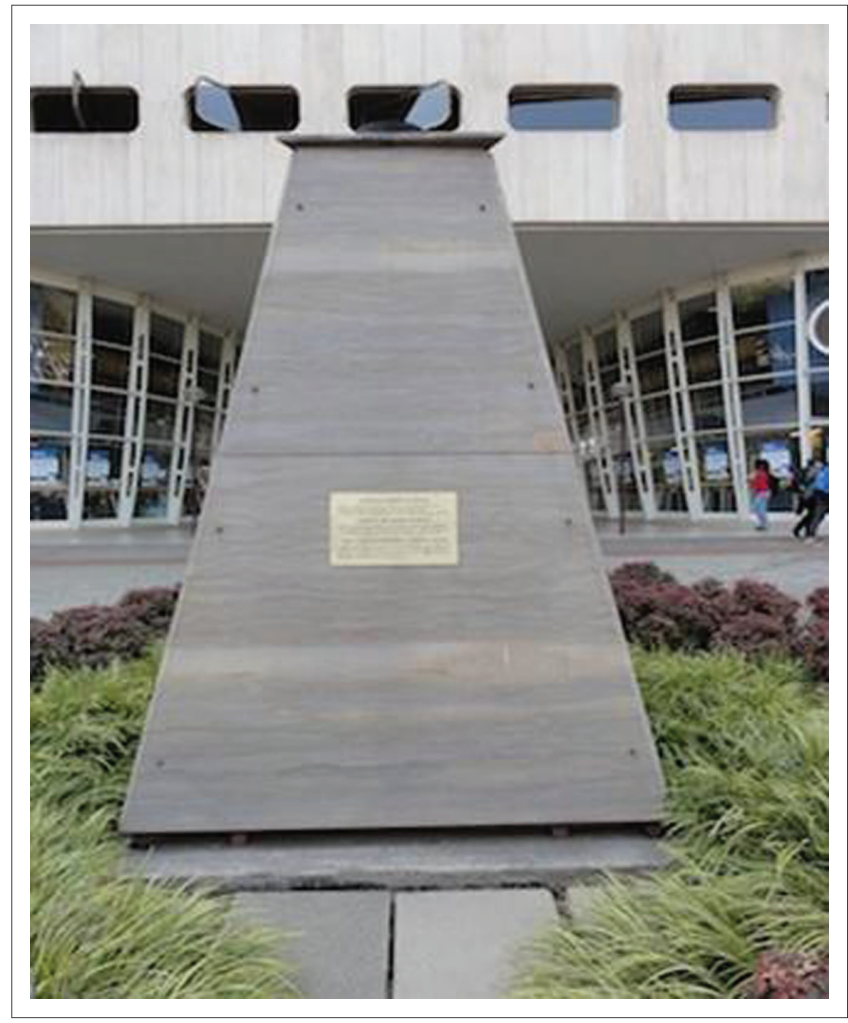

Source: Photo taken by author

FIGURE 3: Eeufees blues 2: The University eeufees (1908-2008) eternal flame without the flame-SASOL no longer fuelling it.

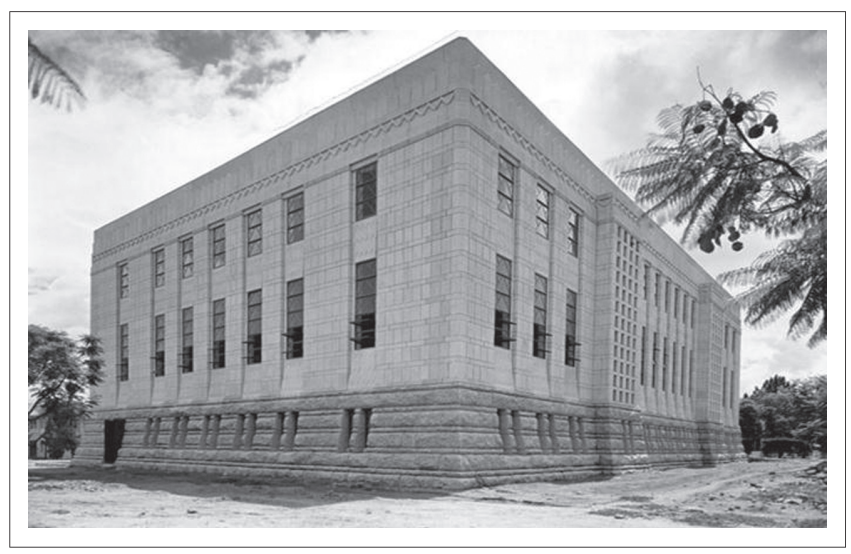

Source: Permission to use photo granted by the University of Pretoria (http://repository.up ac.za/)

FIGURE 4: Merensky Library, designed by Gerard Moerdyk, shortly after completion of construction in 1938.

active until his death in 1990. In true White Economic Empowerment (WEE) tenderpreneurship of 'baantjies vir boeties', he obtained commissions for some of the prominent buildings on University of Pretoria (UP) campus and its surrounds (Figure 8).

He left his imprint with the iconic Administration Building (1968), the Engineering I Building (1975), the new Library Building (1976), the tower block that is the Humanities Building (1977), as well as the Geography Building extension, the men's residences named Boekenhout (1962) and Olienhout (1964), and the women's residences in tower block 


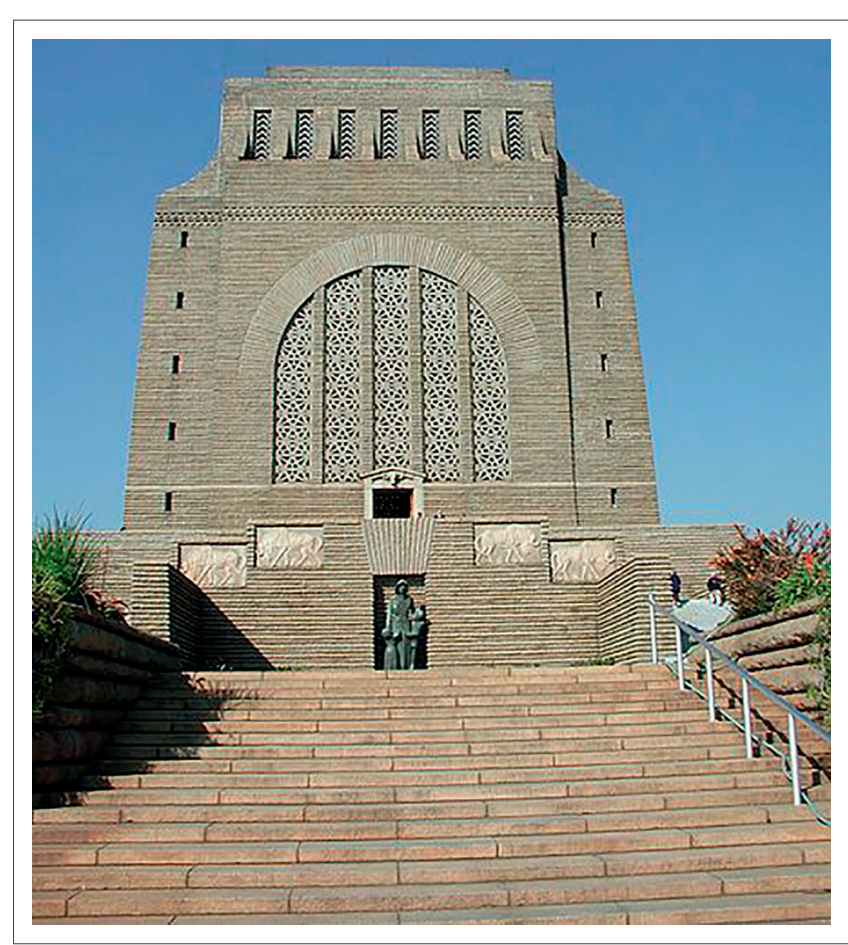

Source: Wikipedia, n.d., Voortrekker Monument, viewed from https://en.wikipedia.org/ wiki/Voortrekker_Monument\#/media/File:Voortrekker_Monument.jpg

FIGURE 5: Merensky Library's Big Brother on the hill: Voortrekker Monument, designed by Gerard Moerdyk, 1949.

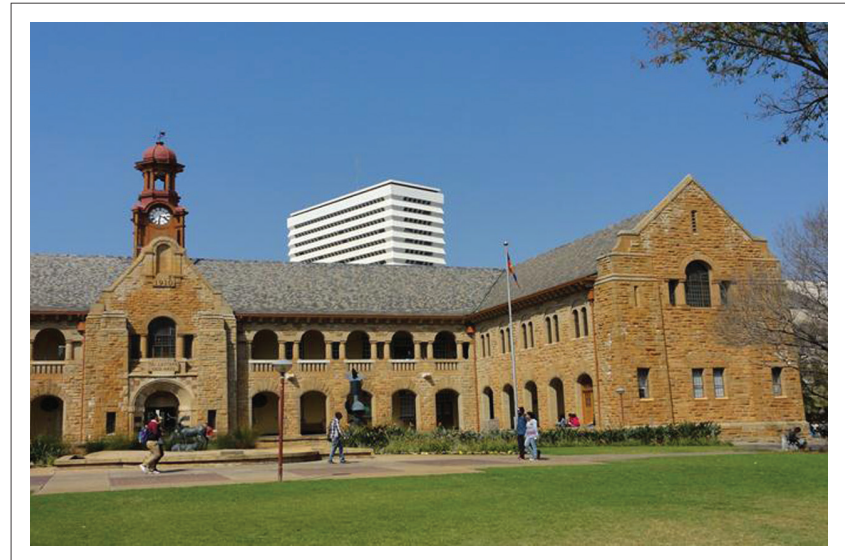

Source: Photo taken by author

FIGURE 6: The Old Arts Building, opened in August 1911, as first building of what was then the Transvaal University College (TUC), designed by Percy Eagle, a student of Sir Herbert Baker, overshadowed by the Humanities Building of Brian Sandrock's design, completed in 1977 - as if to trump General Jan Smuts' vision for TUC announced at the opening of the Old Arts Building, 'that the TUC would one day be to this country what Oxford was to England.'

form, called Erika (1969), Madelief (1977), and Magrietjie (1982) (Figure 9 and Figure 10).

Sandrock's and Burger's designs complemented the National Party and Afrikaner Broederbond's search for 'symbols of purism, power, progress, prosperity, virility, superiority, authority, and impenetrability', and all the more so, 'as the regime's political isolation grew' (Brink 2012:20).

'The flagship of the architecture of apartheid modernity' (Brink 2012:10), Sandrock's Administration Building, is the

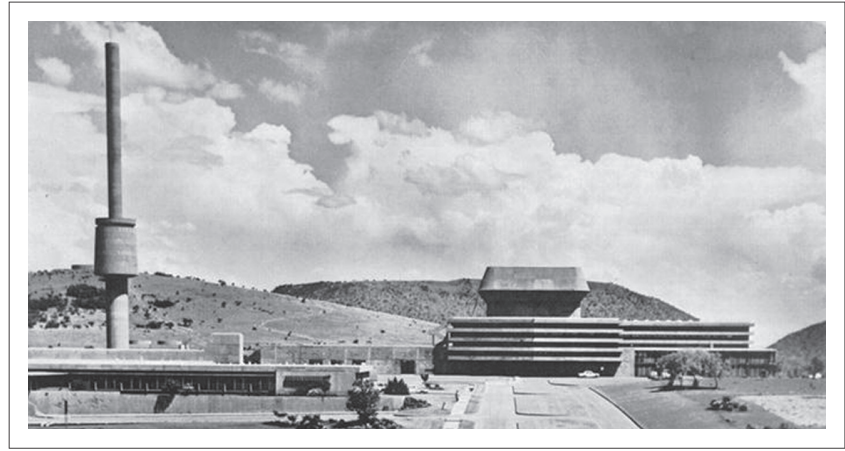

Source: Artefacts, n.d, Reactor and Chemistry Buildings, viewed 09 September 2015 , from http://www.artefacts.co.za/main/Buildings/image slide.php?type=2\&bldgid=9822\& rank $=2$

FIGURE 7: Pelindaba Reactor and Chemistry Buildings, designed by Brian Sandrock, 1965.

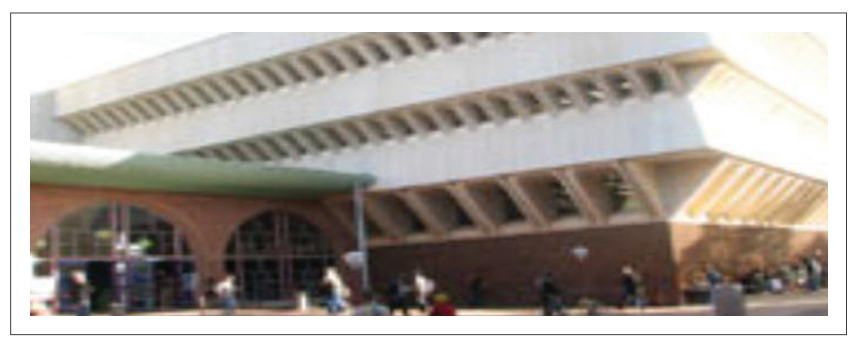

Source: Permission to use photo granted by the University of Pretoria (http://www.library. up.ac.za/images/entrance2.jpg)

FIGURE 8: Merensky II Library, designed by architects Lou, Marais, Marquard and Kuhn, 1975 - assimilating Sandrock's designs.

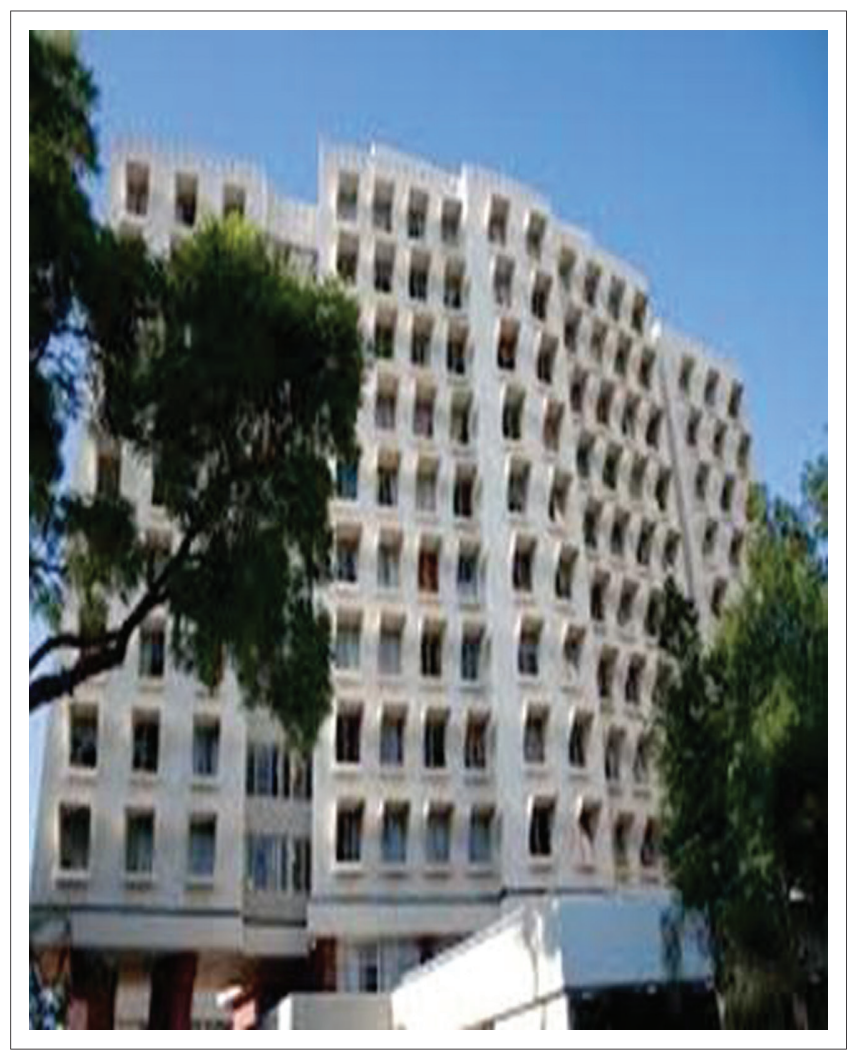

Source: Photo taken by author

FIGURE 9: Women's Residence 'Magrietjie' designed by Brian Sandrock, 1982.

only building in its genre that has a vaguely ornate facade an intricate relief mural that was the result, as Sandrock 


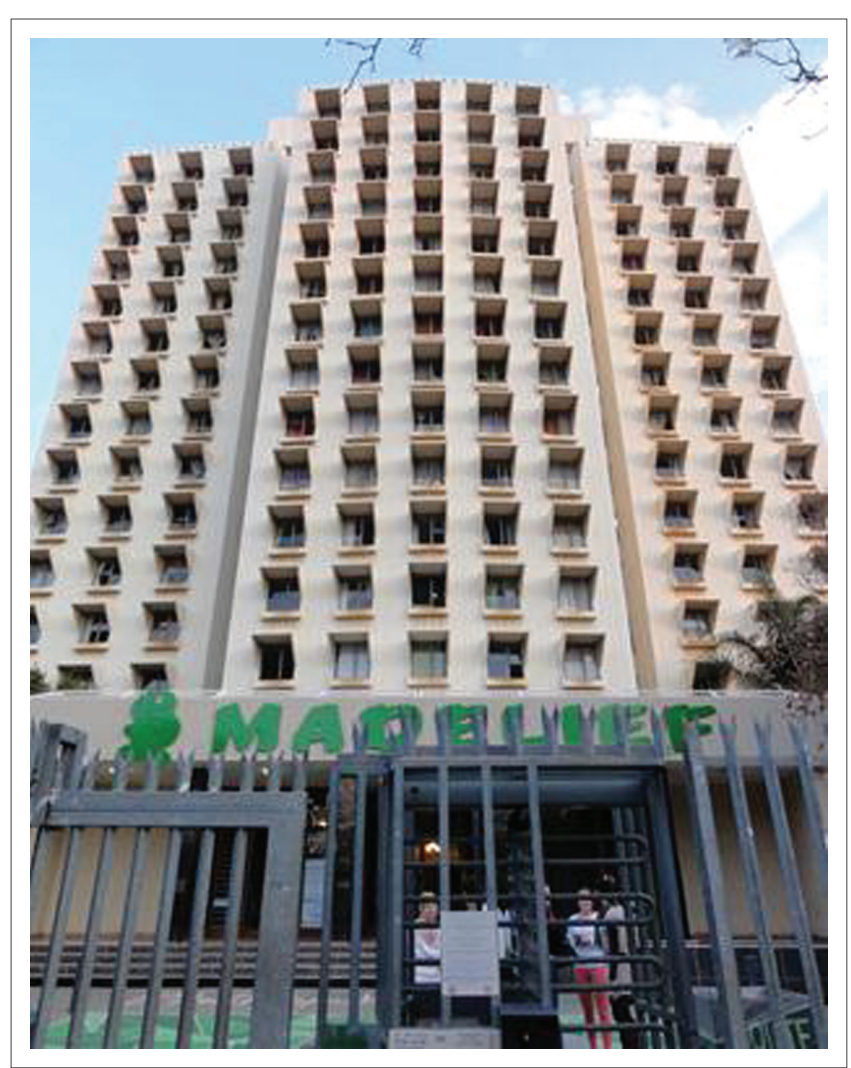

Source: Photo taken by author

FIGURE 10: Women's Residence 'Madelief' designed by Brian Sandrock, 1977.

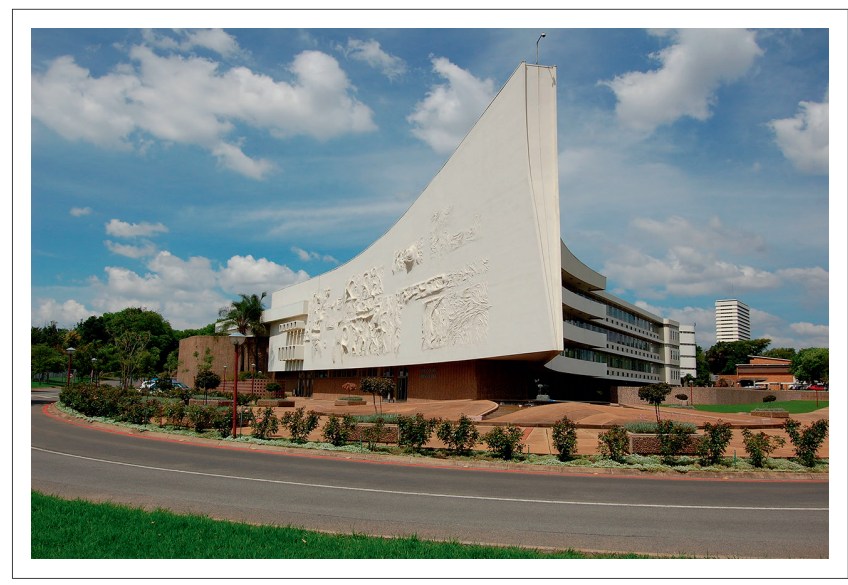

Source: Wikipedia, n.d., Administration building ("Die skip") on its Hatfield campus, viewed from https://upload.wikimedia.org/wikipedia/commons/thumb/d/df/Die_skip_University_ of_pretoria.JPG/1920px-Die_skip_University_of_pretoria.JPG

FIGURE 11: Administration Building ('Die Skip'), designed by Brian Sandrock, 1968

commented, 'of doodling in plaster of Paris late at night while [working] on the model of the building' (University of Pretoria n.d.). It still enjoys pride of place, featuring prominently as trademark band on all UP posters and websites today, in line with Sandrock's idea that the administration forms the centre of a University (Figure 11).

Apartheid modernity was not confined to public architecture, though. It was engineered in tandem with multidimensional 'modernisation' projects encompassing social policy, spatial design, and town and regional planning, which has left an imprint not only on the historical geography of the City, but on those moving in and out of, and between, its urban and peri-urban spaces which became modelled and remodelled as uncertain places of purposeful activity in pursuit of livelihoods, residence, work, civic inclusion, relationality and futures.

In a speech delivered at a Symposium on the Restructuring and Rebirth of the City of Tshwane on 22 November 2001, Sydney Mufamadi, then Minister of Provincial and Local Government, drew out the city's spatial and social geography shaped by this legacy:

For many decades, the previous government together with the former City Council of Pretoria attempted to plan and administer Pretoria as a model apartheid city. The first phase of this process came with the forced removals of Bantule, Marabastad, Lady Selbourne, Eastwood, Highlands and Newlands and the creation of segregated townships on the urban periphery such as Atteridgeville, Mamelodi, Eersterus and Laudium. This had the effect of displacing those who could least afford it furthest away from places of work and economic opportunity. It also destroyed the economic livelihood of many families. The second phase, at the height of 'grand apartheid', came with the establishment of townships such as Winterveld, Mabopane, Soshanguve, Hammanskraal and Ekangala. The aim was to create a whites-only city with decentralised industrial areas such as Rosslyn and Babelegi served by black labour located in 'homelands'... The spatial consequences of displaced urbanisation can be seen in the way Tshwane functional metropolitan region is shaped today: An urban core, surrounded by an inner periphery, where $40 \%$ of the population lives, and Capital cities which produces $91 \%$ of the economic output; an outer periphery in the north-west and north-east, home to $60 \%$ of the population; high volumes of long-distance commuting, requiring huge transport subsidies, between the outer periphery and the urban core every day. (quoted in Mabin 2011:180-181)

While apartheid spatial design has left a lasting legacy of civic disenfranchisement and ongoing dispossession, the exemplars of its once proud public architecture do no longer resonate with each other across the heights and breadths of the City's inner periphery. Its rhizomic moorings slashed, the Pretoria-modernist buildings have become self-referential, uncertain of themselves, fearful of their 'outsides' and 'outsiders', surrounding themselves with security fences and walls, gates and guards.

\section{Musing at the City - From behind the walls of the University or, potshots from the studio}

Having walled itself in, fenced and gated itself off, the University now wants to re-establish a connection with the City - from within and behind its walls - and this is what I would like to describe as the second kind of relation that the University seeks with the City.

An opening salvo was fired for the institutional research theme of 'Capital Cities' by the art exhibition 'Metromusings', 
opened at UP in July 2013, with the idea that 'Art is therapy for the City' (Beaton 2013:96). Metromusing from within and behind the walls of the University, the city centre, with its buildings like those of the Council for Scientific and Industrial Research (CSIR), the Human Sciences Research Council (HSRC), the South African Bureau of Standards (SABS), the Iron and Steel Corporation (ISCOR), and the University of South Africa (Unisa), appears as 'utopian ideal' of 'independence', now 'invaded' or 'fading' (Van der Klashorst \& de Villiers 2013:26, 38); the city centre now being:

$[A]$ place where the homeless gather and seek shelter ... ; a site of pollution; a location where xenophobia flares up easily in the battle for survival and where violence and poverty are palpably obvious on the streets. (Dreyer 2013:48)

Pollution is also pictured as seeping in with 'urban waste water, particularly from informal settlements', which simultaneously indicates 'the repression of uncomfortable emotions, a pushing below the surface of all that is seen as dark and undesirable' (Losgott 2013:81). Imaging the cityscapes, one of the metromusers describes 'the arabesque strokes that cut into the panoramas', suggesting 'something about the invisible presence of time, disruption, and change' in relation to the city - but this something is tenuous, invisible, and cannot, it seems, be named - not even by a native of the city, for whom the city tautologously is what it is (Eksteen 2013:62). Catapulted by this unnameability into the 'postcolonial, post-modern, postapartheid city', the city becomes, to another metromuser, 'an emergence of forms', 'never [to] be explained as a ... structure into which individuals could fit or adapt' (Van der Merwe 2013:89). Another one finds herself challenged to endure in a place of placelessness, unmoored from her 'place of origin', in the face of 'crime and the current political situation' (Van Rooyen 2013:102).

\section{The University and 'The Community': Giving but not giving back}

Not all of the University's engagements with the City are potshots from the studio, though. And with that, I get to the third kind of relation that the University seeks with the City that of 'Community Service', which made its appearance in University mission statements and outreach programmes since the launch of the 'Accelerated and Shared Growth Initiative' (ASGI) in 2007, arguably as partial re-orientation from the contested Growth, Employment and Redistribution (GEAR) Strategy launched in 1996 to stimulate faster economic growth. Subsequent plans and blueprints (programmatic pronouncements on the 'Developmental State' between 2008 and 2010, the New Growth Path announced by President Jacob Zuma in 2010, and the National Development Plan of 2013) place more emphasis on the reduction of poverty and inequality. Oblivious to some of the earlier cautions about the notion of 'community' in development strategies and programmes of immediate post-apartheid reconstruction (see Friedman 1993), the University of Pretoria steps right into that murkiness.

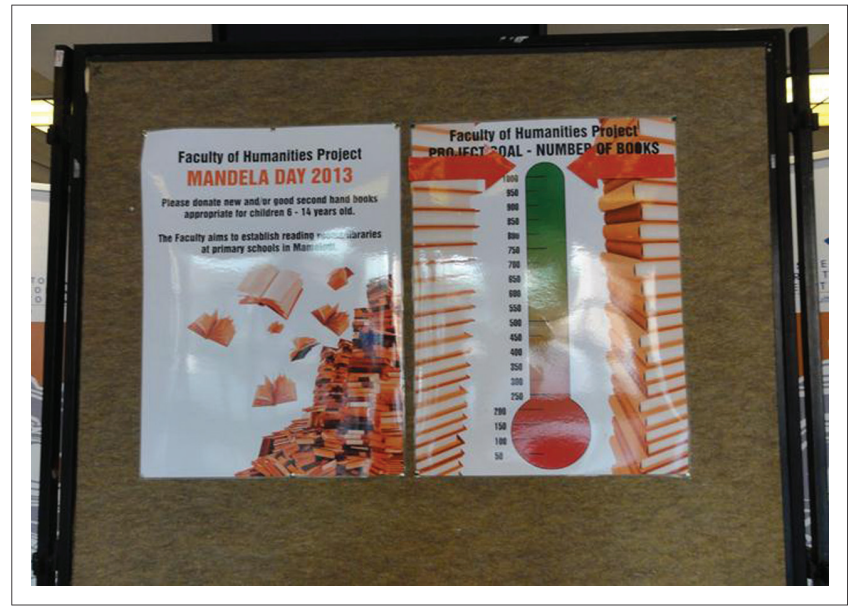

Source: Photo taken by author

FIGURE 12: Book Collection Posters, Faculty of Humanities, University of Pretoria, Mandela Day 2013.

There's some real getting down and dirty, especially on Mandela Day marked on the annual University calendar, when we are urged to give 67 minutes' worth of goodness to 'make the world a better place', cleaning up (in the area surrounding Mamelodi campus) in 2011, painting classrooms of a Mamelodi Primary School (2012), collecting and delivering books to a Mamelodi school, and establishing a reading room there (2013) (Figure 12).

That is when you can see the Principal and the Deans rolling up their sleeves for a photo opportunity (Figure 13).

Last year, 'active community service' collected donations for a vegetable garden and assisted with setting up such a garden, cleaned schools and donated 'pamper packs' to teachers, as well as much needed items in short supply in an Early Childhood Development Centre (Odendaal 2014). Community Engagement projects of the Department of Social Work, Speech Pathology, and the Faculty of Economic and Management Sciences all mount efforts to 'make a difference' to the 'lives of the underprivileged', trying to 'help the community to help themselves', to 'uplift themselves' (University of Pretoria 2011).

So, with so much goodliness and godliness all-round, we may ask, how do we account for the demeaning, stereotyping images to which black women are being held (Figure 14)?

Looking at this photograph, one notices the inscription on a poster hanging on a wall in the background: 'Be Honest, Be Kind', which someone within the social surrounds of this incident has obviously chosen as a motto, to be continuously reminded of. Do we conclude that flaunting the virtues of honesty and kindness in the background of a racially stereotyping performance in the foreground is hypocritical, insincere, bluff and blunder?

I would say not. For there is nothing, in principle, in the choice of the virtues of honesty and kindness as maxims to live by, that would preclude the tacit or overt support for social inequality, racially based supremacism and discrimination, 


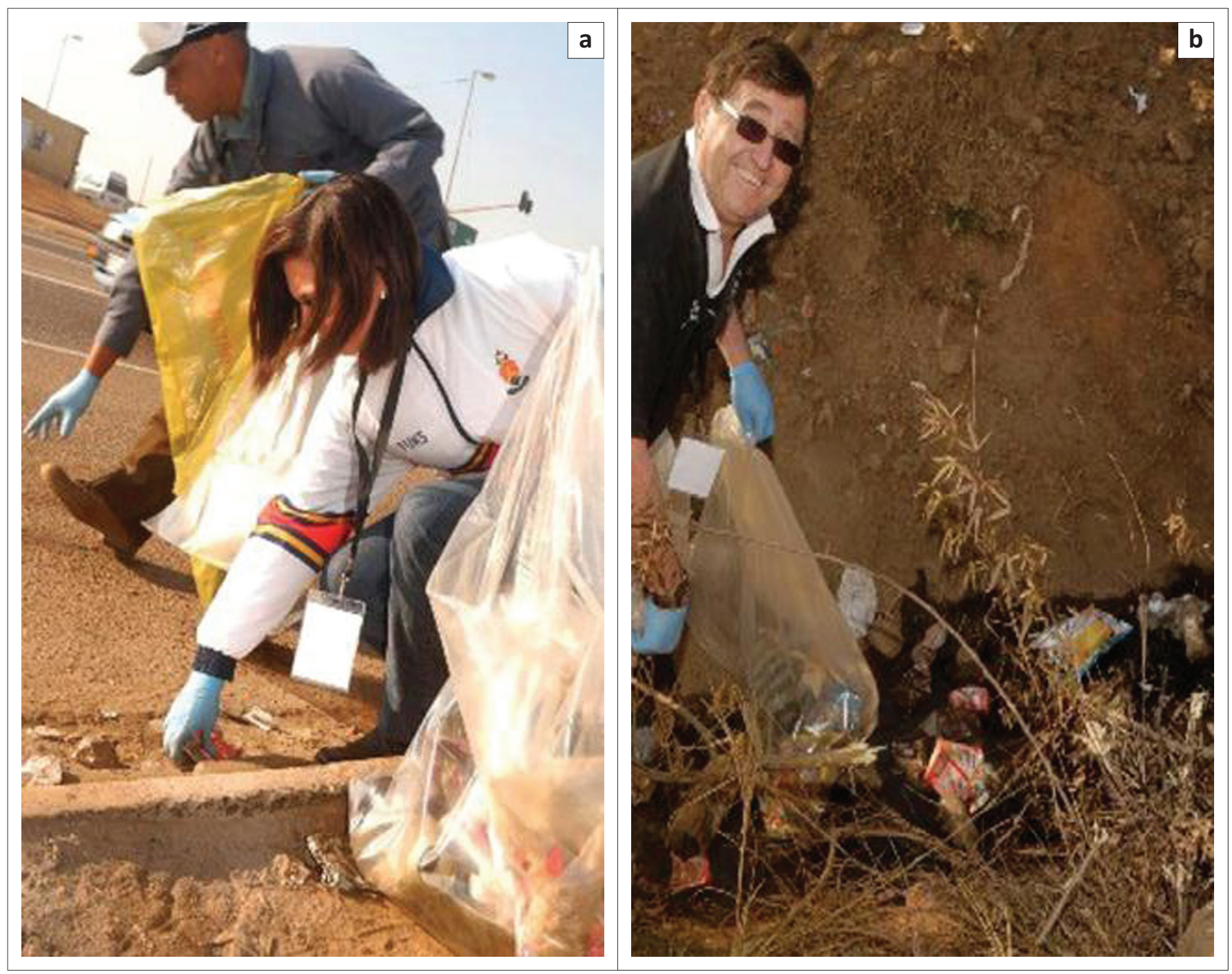

Source: Permission to use photo granted by the University of Pretoria (http://archivedpublicwebsite.up.ac.za/pdfs/8641_The\%20University\%20of\%20Pretoria\%20celebrates\%20Mandela\%20Day.pdf) FIGURES 13: Mandela Day: 67 minutes 'to make the world a better place' - (a) UP Principal Prof Cheryl de la Rey; (b) Dean of the Faculty of Veterinary Sciences, Prof Jerry Swan - 18 July 2011.

patronage and associated attitudes. In fact, I would go as far as saying that these find ready avatars in the acts of goodliness that are promoted through some forms of Community Engagement and 67 minutes of charitability on Mandela Day.

Adapting a quote from Enlightenment philosopher Immanuel Kant's Lectures on Ethics ([1775-1780] 1997:209), one could say that this is a form of kindness (to recall the command on the poster in the background of the 'blackfaces' of the controversial photo) that calls for no reflection and costs no trouble. It demeans its beneficiaries (once more recalling the figures depicted in the foreground of the controversial photo), who tend to receive it with postures of self-degradation.

Kant, in a famous fragment of the 1760s, sums up these considerations in an incisive statement:

Many people take pleasure in doing good actions but consequently do not want to stand under obligations toward others. If one only comes to them submissively, they will do everything: they do not want to subject themselves to the rights of people, but to view them simply as objects of magnanimity. It is not all one under what title I get something. What properly belongs to me must not be accorded to me merely as something I beg for. (quoted in translation in Wood 1999:7)

From this strong statement by Kant, we may draw the following lesson: 'If something is mine as a matter of entitlement, there is something wrong in my being given it back from you as a gift' (Allais 2012:4)

If we do not acknowledge that we enjoy rights that simultaneously place us under obligations toward others, and if this idea of rights is not treated as a fundamental political principle, we can think of such a society as one in which the goods of life are placed under some private persons' arbitrary choices to a greater or lesser degree.

Such is the case with giving to those whom we are habituated to think of as 'needy' - depending on private graces. Our giving then remains perfectly within the social order that generates such a description of personhood - dependent, unfree, humiliated. 


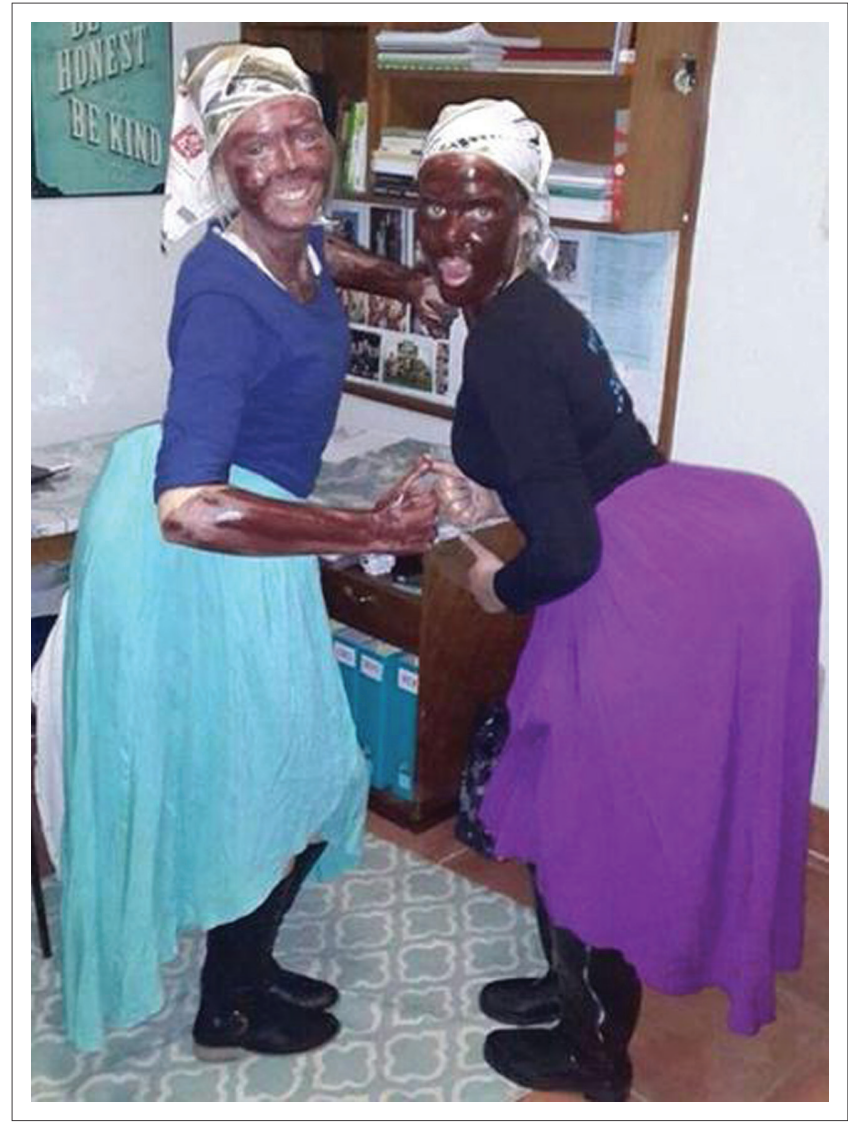

Source: 'Mixed reaction to "blackface" saga', EWN News, viewed from http://ewn co.za/2014/08/06/Blackface-public-reacts-with-outrage

FIGURE 14: 'Blackfaces'.

The persons wronged by the injustice of poverty, are being given as a private gift what they are entitled to as a matter of public right. They are being given it in the wrong - that is, unjust way (Allais 2012:6), and a wrongful relation is being established in the process.

To come back to the question I raised earlier: Goodliness all round cannot amount to justice. One could say, once more with Kant:

In accordance with [benevolence], people are merciful to others and show beneficence to them after they have earlier taken from them, even though they are conscious of no injustice to anyone. (Vorlesungen über Ethik [1793-1794], quoted in translation in Wood 1999:7)

One always talks so much of virtue. One must, however, abolish injustice before one can be virtuous. ('Remarks in the observations on the beautiful and sublime' [1765-1766], in Kant [1764] 2011:168)

Depending for the goods of life on the arbitrary will and whims of others means that 'there is structural injustice of a sort which makes it impossible for you to relate rightfully to these individuals in individual encounters' (Allais 2012:8)

What kind of guidance would the Constitution of 1996 offer to us on this vexing issue? The Constitution that founded a new political dispensation was born out of the most extreme violence. The ensuing negotiated settlement 'enshrined the separation of economic and political domains' (Von Holdt 2013:592): While recognising the legacy of racially based injustice, dispossession and civic exclusion, it protects, to a significant extent, pre-existing property relations and capital accumulation resulting from dispossession, forced removals, and cheap, rightless, migrant labour. The settlement, as Hein Marais (2011:79) notes, was ambiguous: It constituted a dramatic political shift, while leaving socio-economic inequalities intact and open to further contestation (quoted in Von Holdt 2013:593).

The new institutional arrangements have correspondingly marked the social and political forces. The newly enfranchised have become arraigned in contrasting ways: Some few seeking to establish a capital base involving state tenders and assets and corporate partnerships on the one hand, and the many working and survivalist poor, on the other. Both are differentially marked by precariousness: Those 'economically empowered' remain politically dependent on the ANC, and the poor remain in precarious livelihoods.

The economically empowered look for positions, influence, tenders, contracts and other opportunities for accumulating wealth within the state and corporate partnerships, entrenching a contest within and over the state, to subordinate the state and its institutions to the goals of factional interests.

Civically marginalised as precariously living residents are, they do not remain out of the ambits of the contestations of power. Popular grievances are being mobilised by political entrepreneurs to reconfigure power relations within the state at local level. Those called on to support local contenders, in turn, hope for political inclusion in local coalitions and distributive networks promising more sustainable livelihoods into which they cannot come as a matter of right.

\section{'Community enablement' through 'community participation', designing itself away}

Into this politically fractious patchwork of informal and semi-formal sectors and settlements comes another kind of 'community engagement', which I would include as a fourth kind of relation that the University has established with the City. It is one more firmly grounded in academic teaching - for instance in an Honours course spearheaded by UP's Department of Architecture (2015), on Human Settlement and Urbanism under the title 'Community enablement through the critical agency of spatial design', whose motto is 'community participation' (including 'community action planning', 'participatory Geographic Information Systems [GIS]', 'participatory research', 'social capital: networks'). The course outline demands 'community participation' in places where there is none to speak of, speaking of which it then makes its 'intervention'. Oblivious to structures 
of power and their bases and histories, of clientelism and patronage, the course outline enjoins the charting of 'sites of intervention' on a map that it comes to define, as if it were terra nullius: 'Key to this intervention method will be developing a response to the specific people that are identified as the proprietors of the nodal energy points, so that the collective client consists of the people representing that network' (University of Pretoria, Department of Architecture 2015). This method is to be 'replicated in order to establish a basis for appropriate architectural strategies of intervention in various urban conditions' (University of Pretoria, Department of Architecture 2015). Academically based as it may be, this 'intervention method' has taken on board none of the lessons learnt in the immediate postapartheid reconstruction period, principal among which is a 'scepticism, based on political principle'. Steven Friedman (1993) explains:

[W]orking 'with communities' is a complex process and ... success is rarely achieved quickly. Indeed, claims to have secured 'community participation' might be treated with automatic caution ... Claims to have consulted 'the community' may be open to the same objection as appeals by some politicians to 'the people': that they assume that the people (or 'community' is a single organism, with a single mind. In reality, 'the community', like 'the people', invariably includes a wide range of people with differing interests and values. (p. 1)

The claim that development is being negotiated with 'the community' cannot, therefore be taken at face value. It could mean that it is being negotiated only with a section; equally importantly, it may mean that it is being discussed with individuals or organisations who purport to speak for 'communities' but in reality are mandated by a small minority within them. (p. 2)

Private and public developers have attempted to reconcile [the requirement for community participation as a necessary element in projects] with the need for quick results by identifying particular groups as 'community representatives' and then engaging exclusively with them. At times, the result is a bizarre attempt to invent 'community representatives' - more often, it consists of making contact with the most visible leadership group outside official structures. (p. 11)

Driven by academic seasonality - the cramming of 'community enablement through the critical agency of spatial design' into a seven-week module, starting with information sessions at the beginning of February, and concluding with Design Development and an exam in mid-March - on the one hand, and the blueprint Community action plan of the prescribed books ${ }^{2}$ on the other, 'community consultation' would almost inevitably take the form described and critiqued by Steven Friedman.

In Westfort, according to reports of some residents, the specific people identified 'as the proprietors of the nodal energy points' turned out to be a feared local strongman and

\footnotetext{
2.The key text identified here is the book by Hamdi and Goethert (1997). The design of the module is not immune to the charge that 'community participation processes... begin only after projects have already been designed: the process is not an attempt begin only after projects have already been designed: the process is not an attempt
to ascertain priorities but to gain acceptance for an already assembled package' (Friedman 1993:34)
}

his gun-toting entourage, presiding over the 'community consultation' thus engaged in. ${ }^{3}$

In the middle of the Design Development process for the 'Westfort cultural landscape' and other 'research sites' identified for the BArch Hons module, stands were being laid out for a medium to high density development in Fort West Extensions 4 and 5, destroying much of the 'cultural landscape'. At that stage still, there had been no consultation with residents about development plans, housing lists, tendering processes, labour recruitment for the development, and the future of the settlement as a whole.

On the day on which the Department of Architecture (University of Pretoria, Department of Architecture 2015) hosted a round table discussion on 'The Shared Cultural Heritage Program of the Royal Dutch Embassy in Pretoria about the significance and future of the Westfort cultural landscape' (24 March 2015), the first 20 of 81 parcels of municipal land earmarked for auctioning off (Westfort Extensions 4 and 5 being among them), went under the hammer in Summer Place in Hyde Park, Johannesburg - but the sale of two of them was interdicted by a High Court order against the Tshwane municipality shortly beforehand.

And this is where the 'partnership' between the University and the City moves into the middle of civic-political contestation.

\section{The corporate City and the corporate University in corporate partnership}

This contestation marks the fifth type of relation between the University and the City - namely that officially announced as the 'strategic partnership' between the Tshwane Metro Council and the University.

I would like to take a closer look at some aspects of the conditions of life and politics at one particular site in the west of the capitalising city on the one hand, and the 'collaboration', the 'common vision and interest', the 'mutually beneficial relationship' sealed in the 'Memorandum of Understanding' (MoU) signed by the University and the City, on the other (see Tsunke 2013) (Figure 15).

I am contrasting conditions of life and politics at this site with the announcement of a collaborative 'partnership', because of the big gap that divides them. Ostensibly for the benefit of 'the community', the 'community' remains selectively included and excluded, along political fault lines.

The settlement in the former Westfort hospital today accommodates 2000 to 3000 households (Figure 16).

3.Again, Steven Friedman's analysis provides numerous caveats about the assumptions of 'community participation': '[C]ommunity participation exercises often begin with contact between the agency and the most visible ... group and the intention is then to broaden participation. This often gives the group contacted great informal powe to broaden participation. This often gives the group contacted great informal powe over the process. ... [E]xclusionary relationships formed between developers and civics at the beginning of a project are extremely difficult to undo later; where a process has begun with one party, its rivals may refuse to participate since the nitiative is branded as someone else's property' (Friedman 1993:30). 'In som areas, violence forms a backdrop to development negotiations and this obviously constrains any attempt to negotiate agreed solutions - besides the obvious point that violence can obstruct actual development work' (Friedman 1993:31). 


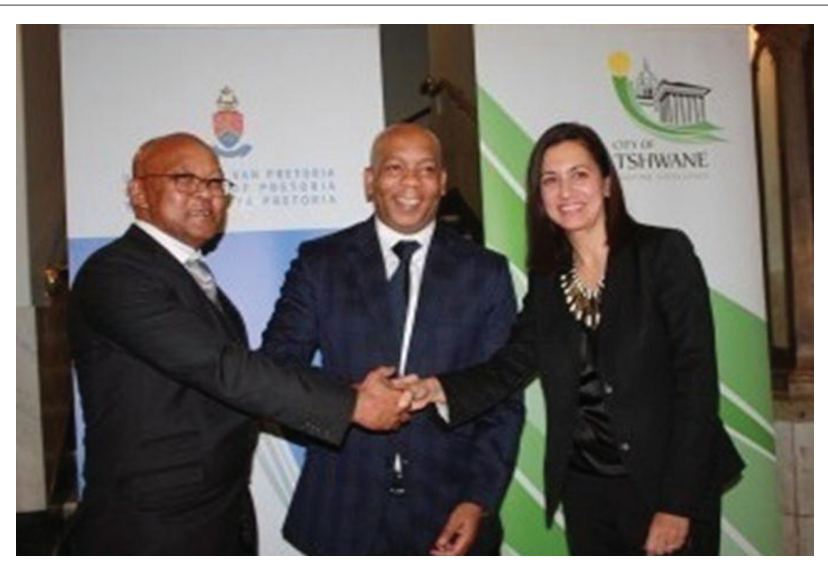

Source: Permission to use photo granted by the University of Pretoria (http:// archivedpublicwebsite.up.ac.za/pdfs/8641_Capital\%20Cities\%20Project\%20launched\%20 in\%20conjunction\%20with\%20City\%20of\%20Tshwane.pdf)

FIGURE 15: Handshakes at the launch of the Capital Cities Project, 08 October 2013

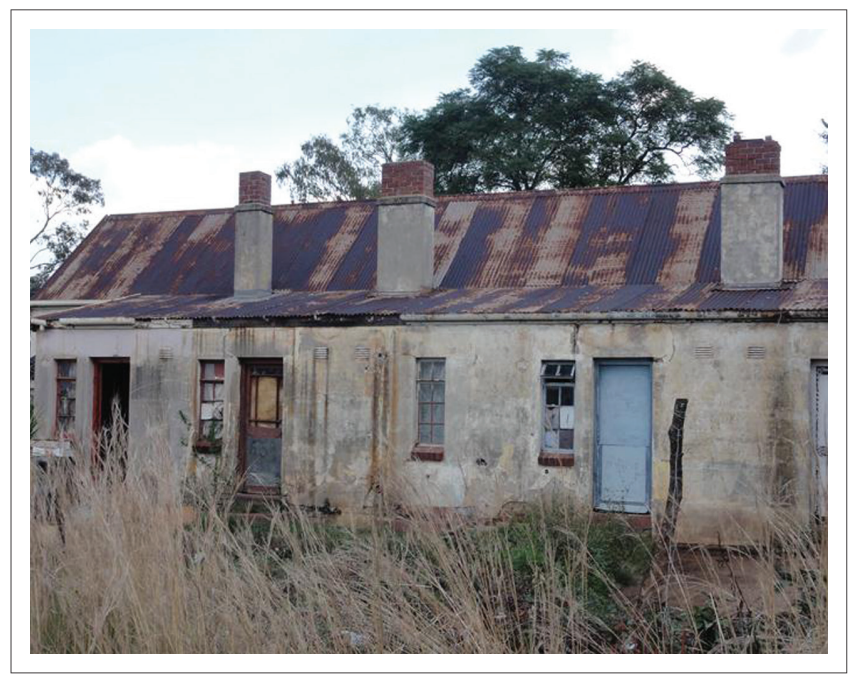

Source: Photo taken by author

FIGURE 16: Rooms in a row, Westfort Hospital settlement, April 2013.

Most of the adult residents of Westfort are unemployed and/or derive a small income from work in the informal sector. Called 'illegal squatters' by the City and the National Heritage Council, those so designated are relegated to a-legality, of uncertain civic status. In an apparent attempt to evict the residents through a new form of influx control (see Selmeczi 2011:65), the City Council disconnected their water and electricity supply, and waste removal in 2004 (Figure 17).

Residents now survive off generators, wood fires, and water brought in by tank usually twice a week, but in insufficient amounts and at irregular intervals. Environmental degradation is extensive. Residents are subject to constant threats of eviction and demolition of their homes, and of the entire settlement, due to housing developments encroaching on the site from the east (Figure 18).

No public consultation has taken place about these developments, and plans and information on tendering procedures are difficult to obtain and contradictory. Housing

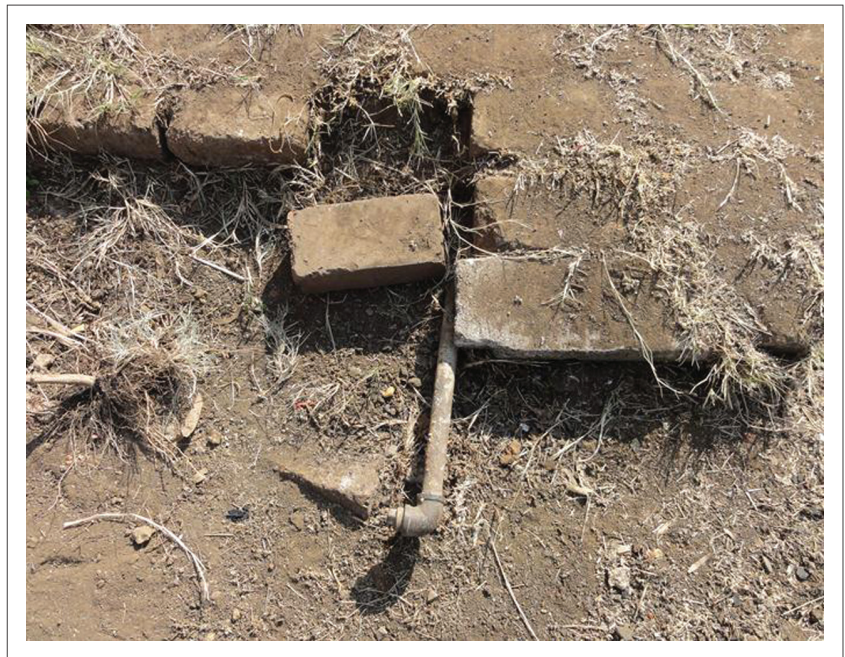

Source: Photo taken by author

FIGURE 17: Plugged water pipe in Westfort-disconnected in 2004, photographed 9 years later in April 2013.

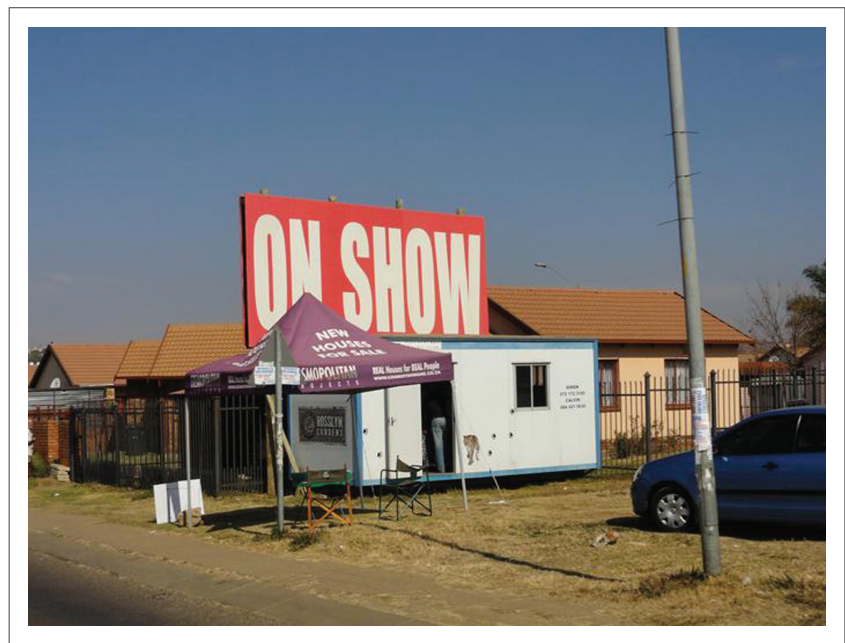

Source: Photo taken by author

FIGURE 18: 'New houses for sale' in housing developments encroaching on Westfort Hospital Settlement, June 2013.

lists, including information on the processes and criteria of their compilation, as well as on the process of housing allocation, are non-existent, adding to the uncertainty of residents, and foiling their attempts to visualise and plan their futures.

The hospital complex is listed as a provincial heritage site, but no maintenance, restoration and protection of the site has been undertaken. Other than notices appearing on fence posts and brick structures from time to time, with contradictory announcements, plans for the site have not been made public (Figure 19).

Residents' tenuous hold on housing in the settlement is more or less secure according to the tune of the payments and services rendered to the African National Congress (ANC) ward councillor, deposed by a residents' committee, but still on the Council's books, and his entourage, who move in and out of the settlement with deals to be struck, fees to 


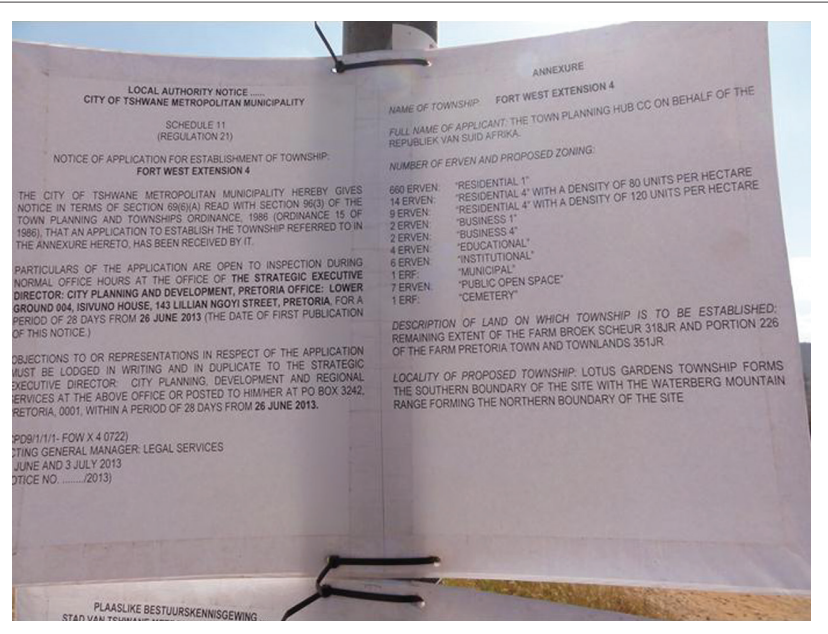

Source: Photo taken by author

FIGURE 19: Local Authority Notice of Application for Establishment of Township Fort West Ext 4, July 2013.

be collected and benefits to be selectively dispensed to those loyal to them (Figure 20).

The ward councillor draws some of his support from the people who claim prior rights to the place, now living uphill from the hospital settlement (in a section called Dobsonville, formerly Davisonville, named after one of Westfort Hospital's medical superintendents), in rows of former staff cottages equipped with telephone lines, electricity, piped water, and sanitation (see Kistner 2014) (Figure 21).

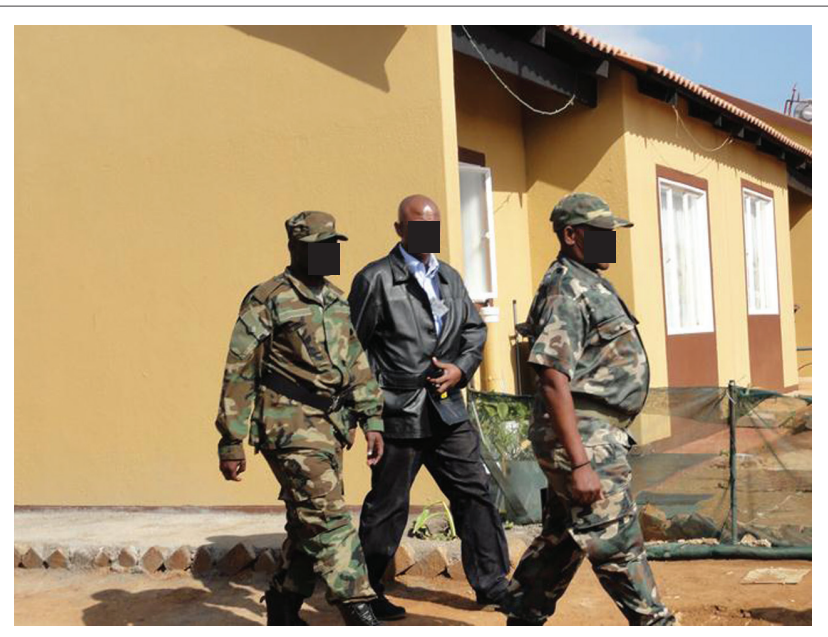

Source: Photo taken by author

FIGURE 20: Councillor and entourage moving through Pretoria West, 18 July 2013

Some of the residents undertake ever renewed attempts of securing a livelihood and gaining access to education and health facilities, to representation in civic structures and the media, to programmes for young people, and initiatives promising civic inclusion, political engagement and public participation. (There's no lack of 'community engagement' there.)

Some enthusiasm gathered around the Tshwane mayor's announcement of a 'massive job creation initiative aimed at empowering the youth of Tshwane, known as Tshepo 10000 ,

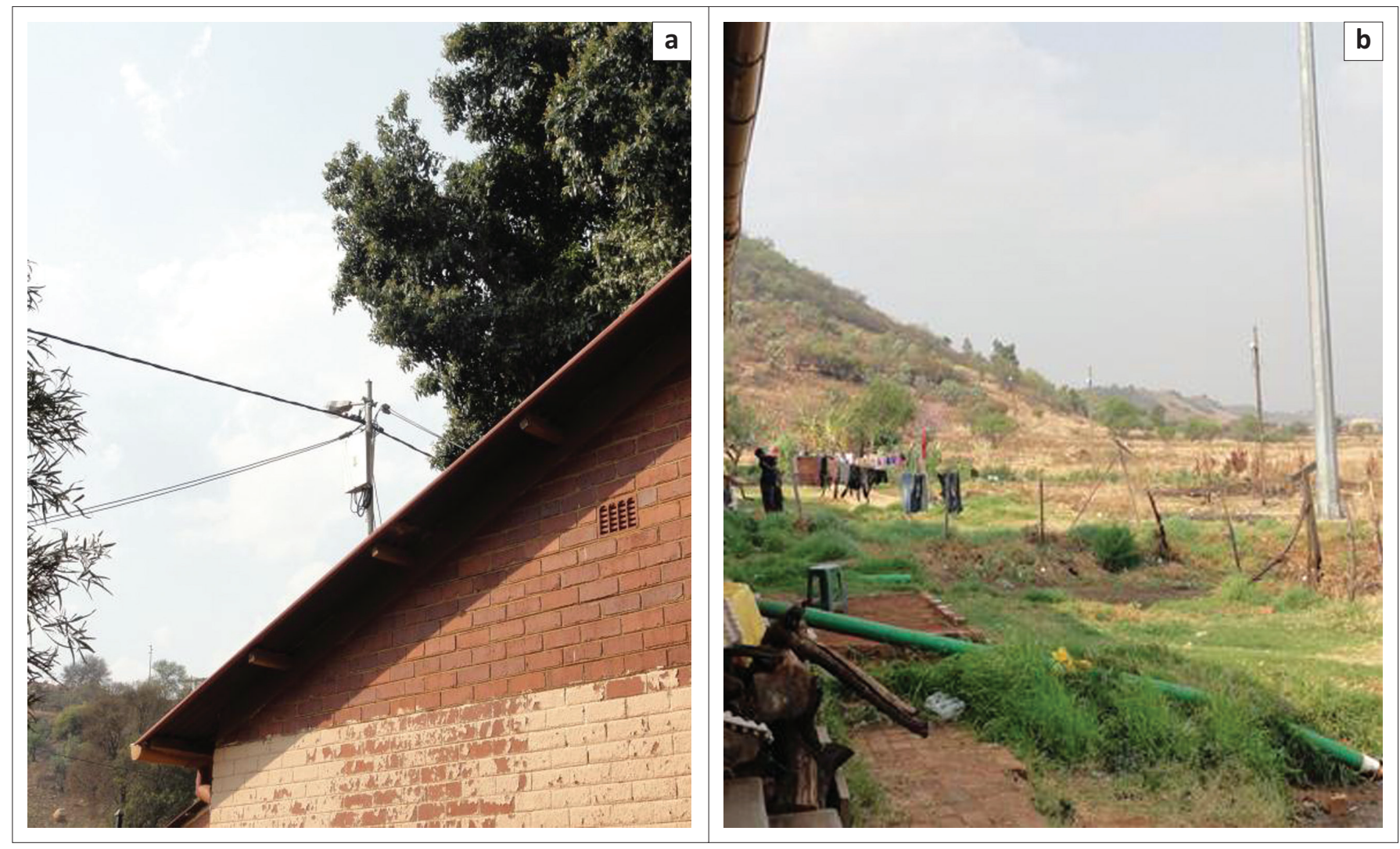

Source: Photo taken by author

FIGURES 21: Dobsonville - (a) with power, telephone and (b) washing lines, and water pipes, December 2012. 
at a press conference ... on ... July 25, 2013' (City of Tshwane 2013). The announcement promised that:

The selected candidates [would] undergo rigorous and intensive training at the University of Pretoria (UP) and the Tshwane University of Technology (TUT) which would empower them with the necessary skills and expertise, to make them eligible to tender for procurement projects to the value of a staggering R1,1 billion, which is $25 \%$ of the City's total capital expenditure budget. (City of Tshwane 2013)

The next day, the Pretoria News reported this announcement under the heading, 'Tshwane has 10000 jobs for residents' (Van Zuydam 2013). Among the details in finer print, the article also mentions a promise that 'candidates will receive a stipend to cover their food and transport for the duration of the training.' The programme was ceremoniously launched at the Pretoria Show Grounds on 05 September 2013.

In what was to become a self-fulfilling prophecy for a young woman from Westfort, Mayor 'Ramokgopa said unemployment robbed individuals of their dignity and selfrespect and eroded their standard of living. It also affected society as a whole' (Molopyane 2013).

Hopeful, expectant, and proud to have been 'chosen', this young woman from Westfort enrolled in the job creation and training programme, taught by staff of UP's Economic and Management Sciences Faculty, UP's Continuing Education and ABSA, in September 2013. I saw her again three months later, at the end of November. She looked in bad health, and from what I could gather, hadn't had a proper meal in days. She had to take her son out of pre-school, she told me, because she couldn't pay the fees. The course for which she had been registered, with the promise of meal tickets and transport and job prospects at the end of it, did not live up to her expectation. No meals were provided, participants had to fork out their own transport money, and the job that, in her understanding, had been promised, did not materialise. (Many of the comments on the blogs of various sites reporting on Tshepo 10000 echo this experience.) She alleges that the course organisers were pocketing the money officially dedicated to 'job training for job creation'. Attempts to get the Pretoria News to investigate the programme three months after its launch, tracking and interviewing the participants initially enrolled, met with no response. (In the meantime, also, UP's Journalism Programme, which would have had some tentacles into the City, has been closed down.)

All the while, the glamour side of the 'strategic partnership', on the Web pages of the University and the camera flashes capturing official signings, congratulatory handshakes, launches, openings and inaugurations, proceeds apace (Figure 22).

The collaboration on 'entrepreneurial development projects, aimed particularly at the youth,' on 'the training [of] micro, small and medium enterprises in the Pretoria community' is being upheld as a contribution of the University 'to the development and growth of Tshwane,' for 'mutual ...

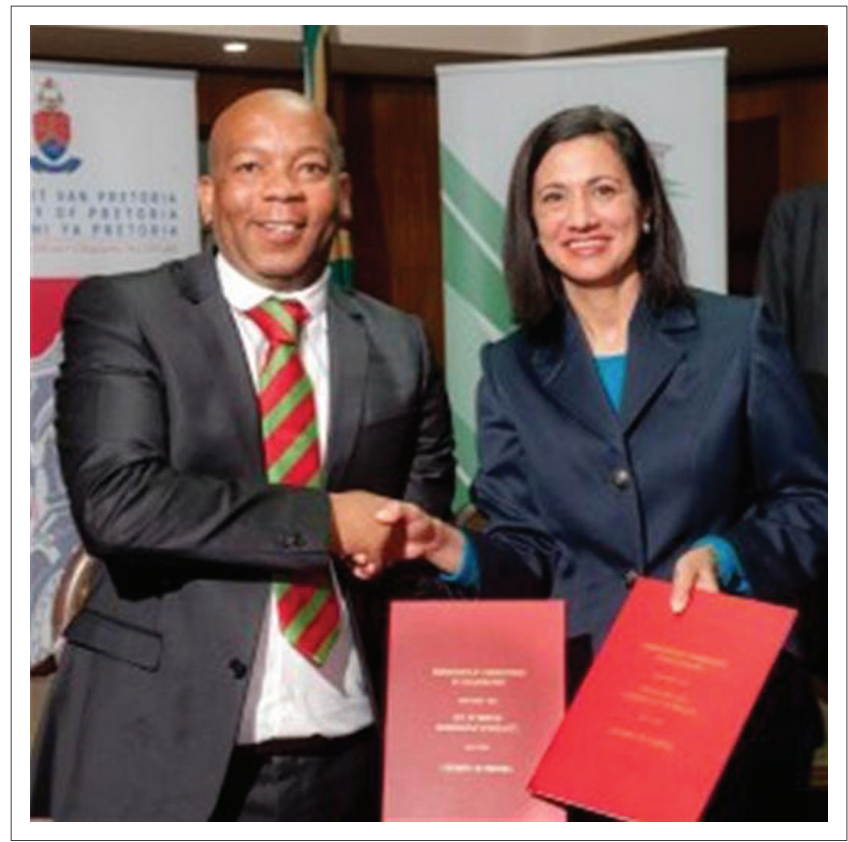

Source: Permission to use photo granted by the University of Pretoria (http:// archivedpublicwebsite.up.ac.za/pdfs/8641_Capital\%20Cities\%20Project $\% 20$ launched\%20 in\%20conjunction\%20with\%20City\%20of\%20Tshwane.pdf)

FIGURE 22: Photo session after signing a MoU between UP and City of Tshwane, July 2013.

benefit', for 'positioning Tshwane as a knowledge economy' to 'compete favourably with others on a global scale', and for 'mak[ing] a difference in our communities' (Tsunke 2013).

'The African City of Excellence', global competitiveness, and strengthening investor confidence, are recurring themes in the mayor's annual State of the Capital address ${ }^{4}$ and related public pronouncements referring to the "Tshwane Vision 2055', which in turn takes its cue from the National Development Plan 2030. Such programmes for economically competitive urban 'development' are more likely linked to the 'militarization of urban space', effecting 'slum eradication' through eviction and systematic displacement, migration and homelessness (Gibson 2011:20; Huchzermeyer 2011:54; also Murray 2008:14). ${ }^{5}$

\section{Descending from the summit of homelessness}

More recently, another modular block has been added to the 'partnership' between the University (in this case both universities in the city, viz. University of Pretoria and University of South Africa) and the City: The Tshwane Homelessness Forum, and a number of international organisations working on homelessness through research, advocacy, policy, and 'solutions'. ${ }^{6}$ Launched in December

4.Thus, also in the "State of the Capital Address of 2015 , embellished with a flourish from the capital citadel: '... for excellence to be ignited and sustained, we need an army of men and women who populate the City of Tshwane to be fully imprisoned by a superior sense of duty' (Ramokgopa 2015).

5.This is what motivates Huchzermeyer's insistence (2011:10) that 'a 'right to the city' cannot be promoted without challenging the norm of "Cities Without Slums".'

6.These include the Institute of Global Homelessness, De Paul University, Chicago Centre for Equity Studies, Delhi, India; Community Solutions, New York City; and International Street Medicine. 
2014, this collaboration aims to 'provide strategic leadership to the research and strategy development process'. More specifically, it wants to give 'greater visibility, awareness, and understanding' to the issue of street homelessness in the City of Tshwane, to make 'policy recommendations', and to propose 'strategies for preventing and/or reducing homelessness' (University of Pretoria, University of South Africa, City of Tshwane, Tshwane Homelessness Forum 2015) - in what I would like to consider as a sixth kind of relation between the University and the City. It is an extremely ambiguous one, highlighting the conflictual and destructive potential of 'development' (see Friedman 1993:41). Under the auspices of the newly forged 'strategic partnership', a 'Homeless Summit' was convened in May 2015, charting 'pathways out of homelessness' (Pathways out of homelessness 2015), engaging in 'interactive discussions' and 'conversations', staging 'narratives of (former) homeless people', 'celebrating resilience', formulating 'policy and strategy' and 'mapping the way ahead' with 'strategy and investments' and a 'social contract' (Homelessness Summit programme). Sessions were presided over by 'Programme Directors' from UP and the City. The Tshwane executive mayor, in his curtain-raising role, gave his blessings (and a gala dinner) - the same mayor who threatened and implemented 'painful measures' to 'clean up Pretoria city centre' regardless of 'casualties' (Cleaning up Pretoria painful 2012), ${ }^{7}$ and to 'rid the city of its estimated 160000 illegal squatter shacks within this financial year' (Massive municipal land 2015), ${ }^{8}$ thus - in the absence of consultation and provision of alternative accommodation - contributing to homelessness in the city.

Dr Stephan de Beer, Director of UP's Centre for Contextual Ministry, sounded the clarion call: 'a politics of compassion, generosity, and justice.' He explains:

What we are embarking on is really a new kind of politics by all of us, coupled by new practices and learning how to be human together. So it requires politics of compassion, moving from labels of language, calling people vagrants, hobos, tramps, and all the rest, to a deep appreciation of people's God-given dignity. (Naicker 2014)

7.The formulation " 160000 illegal squatter shacks" here is instructive. It contains an ambiguity, due to a double attribution: 'Illegality' is made to pertain to both 'squatters' and 'shacks'. By virtue of their allegedly unlawfully erected dwellings, the people erecting and/or inhabiting those dwellings become 'illegal'. Furthermore, the number of shacks gives an indication of the massive scale of the City's divestment. If we were to considicinent. we were to consider a shack home to an estimated average of 3 persons, we would obtain a figure of half a million people being considered illegal'. In the absence of criteria for housing allocation, and general lack of consultation, information and communication on housing construction and allocation, the practice of labellin residents 'illegal' and subjecting them to uncoordinated measures experienced as arbitrary harassment, can only contribute to insecurity of tenure, title, rights, and civic participation.

8.The figure of 'illegal' shacks roughly corresponds to the 2011 census data, giving the figure of 164014 households living in shacks (backyard and other combined) in Tshwane municipality (see Housing Development Agency 2013:16), in 124 informa settlements in the municipal area (see Ramokgopa 2015). In the period between the 2001 and the 2011 census, access to refuse removal in informal settlements in Tshwane declined, with the figure of households without access to any form of waste removal increasing by $4 \%$; access to electricity declined; and access to water and sanitation improved marginally over the same time period (Housing water and sanitation improved marginally over the same time period (Housin Development Agency 2013:20, 21,34). 136000 children under the age of 18 were found by the 2007 Community Survey to live in shacks (in shack settlements in Tshwane) (Housing Development Agency 2012:35). Another noteworthy finding of the 2007 Community Survey is that a large portion of people living in the City of Tshwane in a shack not in a backyard had been living there for an extended period of time. Across the municipality, 49\% said they had not moved since 2001' (Housing Development Agency 2012:36).
The Summit, in particular, De Beer says:

[W]ould like to explore the possibility of a city that is humane, socially just, compassionate and generous to all of its inhabitants, including those who have to sleep on its streets every night. (Pathways out of homelessness 2015)

What to make of the apparently contradictory soundings of the Summit's high profile curtain-raisers, programme directors, facilitators and sponsors? Rather than getting carried away by any notion of a miraculous transformation by which the lamb and the wolf come to bleat together in harmony in the course and the spirit of this collaboration, I would want to suggest that they represent opposite sides of the same coin in a complementary relation: Property, with law, 'reasonableness', self-sufficiency and personal autonomy on its side, on the one hand; and poverty, associated with 'lawlessness', 'unreasonableness', civic exclusion, marginality, need, lack, personal deficiency and heteronomy, on the other. This opposition plays itself out on the ground:

When inhabitants of [informal] settlements, often in defence of their livelihoods, organise and struggle for the exception of in situ upgrading rather than the norm of removal/relocation, they have to compete with emerging plans for productive development or profitable investment on the same land. (Huchzermeyer 2011:11)

A deeply political divide spanning historical and ongoing dispossession, displacement, homelessness and destruction of 'community' is tendentially translated into a 'social problem' adhering to 'community', where it solicits responses of social concern and compassion, appropriating the disappropriation of the wrong (see Rancière [1995] 1999:139). ${ }^{9}$

This response and the corresponding interventions are highly circumscribed. They are conditional upon the privative status by which they mark their object: homeLESSness. The other side, that of property, law, reasonableness, et cetera, kicks in the minute that those held in a privative, receptive, passive, inert status assume agency and become restless and restive. 'The law has always found it difficult to deal with representatives of [the latter] group', property law theorist André van der Walt (2009) explains, mostly because they:

$[N]$ ormally encounter the law only in conflict with the established rights of central legal players (fugitive slaves, trespassers, squatters, intruders and encroachers) or when they demand exceptional accommodation founded not in law but in compassion (children, the poor, the homeless, the hungry, the unemployed, the sick and the disabled) [i.e. those whom we like

9.Jacques Rancière cautions against measures aimed at 'mending the community fabric, to give back to each person excluded the identity of a mobilized capability and responsibility, to establish in every derelict dwelling a cell of collective responsibility.' Rancière ([1995] 1999:117) explains: 'The social reject and the abandoned urban wasteland then become models of a "new social contract" and and a new citizenry, thrown up at the very point where the responsibility of the individual and the cement of of the social bond were crumbling. Some extraordinary minds and souls are employed in this process, and the results are not negligible. There remains the circularity of a logic aimed at sticking the supplement of a bond everywhere in society as well as motivation in the individual, when the of a bond everywhere in society as well as motivation in the individual, when the problem with either sphere is strictly the effect of such an unstoppable saturation endeavor of the unconditional requirement of mobilization. There remains as well the demonstration of the exact identity between sickness and health, the norm of saturation of consensus and the dereliction of downtrodden identities. The war of all against all, the constitution of each individual as a threat to the community, are the strict correlate of the consensual requirement of a community wholly realize as the identity between the people and the population reflected in each person.' 
to think of as 'the community' deserving of our sympathy].... For the law [and the responses out of 'social concern'], these individuals and groups are normally either criminals or beggars; they do not receive justice so much as either punishment or benefaction. (pp. 19-20; additions in square brackets by author)

Punishment, extrusion, and benefaction form the parameters of this 'partnership'.

These two sides are brought into confrontation with each other by a shift in legal focus, impelled by section 26(3) of the 1996 Constitution (South Africa 1996) seeking to prevent and reverse apartheid-style forced removals, and by subsequent legal reforms limiting evictions without consultation and arrangements for alternative accommodation, and provision for the needs of the most vulnerable (e.g. the Prevention of Illegal Eviction from and Unlawful Occupation of Land Act 19 of 1998 [South Africa 1998]). Human rights and constitutional law are beginning to bring this shift to bear on assured self-confidence of the Council as it embarks on land auctions, evictions, less than transparent tendering processes, development plans bypassing consultations with residents and violating the constitutional right to housing for homeless people and those living in informal settlements (see Mudzuli 2015). However, this civic challenge to the City of Tshwane has not (as yet?) made a dent in the 'strategic partnership' of the University and the City. A challenge will have to come from elsewhere.

\section{Engaging the University from a space of a-legality}

Few as they are, the constitutional inroads into the propertypoverty complex tendentially crack it open, intimating, as Hans Lindahl shows by reference to the land occupations of the Brazilian Landless Workers' Movement (Movimento dos trabalhadores rurais sem terra [MST]), 'a place that has no place in the distribution of ought places actualized by the ... legal order, yet which, they claim, ought to' (Lindahl 2013:53). We can catch glimpses here of a de-centring of the dominant property regime and the way in which it draws the legal-illegal distinction, with potential effects of forcing shifts of entitlements, law and legitimacy (Lindahl 2013:54). In the process, 'the non-legal emergence of the distinction' between legality and illegality as drawn by a legal order (Lindahl 2013:152) is revealed. The privative, static, inert, ahistorical and apolitical definition of homelessness and landlessness, so dear to the most recent addition to the 'corporate partnership' between the University and the City, unbeknown to itself, harbours another - the seventh and for purposes of this article, last possibility: That of propertyoutlaws exploring a range of unanticipated practical possibilities of operating in a space of a-legality as a different distribution of ought-places outside of the exclusive 'legal''illegal' distinction (Lindahl 2013:54), exposing a normative fault line in relation to the latter.

If the call to 'community' comes from outside of itself, being indicative of the very division fracturing it, and we thus cannot think of 'serving', 'empowering', or 'enabling' an undivided, originary 'community' (enunciated from the other side of the divide that defines 'community' as 'the others'), perhaps, rather than talking about 'community engagement', 'community enablement', 'community participation', or 'partnerships' with and for the privatively defined 'community', I would suggest, we would need to start talking about engagement of the University, about engaging the University, and about the engaged University (see Paphitis \& Tabensky 2013). Taking a leaf from the practices of exploring a different distribution of ought-places through the openings provided by a-legality, we would hit upon the productive powers of dissensus within the University - refusing the false alternatives requiring a choice between 'the enlightenment of rational communication' and what the light of rationality can only cast as its shadow: The benightedness of the irrational, of irreducible difference, and of life below or beyond the pale (see Rancière [1995] 1999:43).

\section{Acknowledgements Competing interests}

The authors declare that they have no financial or personal relationships which may have inappropriately influenced them in writing this article.

\section{References}

Allais, L., 2012, 'Kant on giving to beggars', viewed 12 August 2014, from wiser.wits. ac.za/system/files/seminar/Allais2012.pdf

Artefacts, n.d, 'Reactor and Chemistry Buildings', viewed 09 September 2015, from http:// www.artefacts.co.za/main/Buildings/image_slide.php?type=2\&bldgid=9822\&rank=2

Beaton, L., 2013, 'Prompt: Performance and video', in Metromusings, pp. 94-97, University of Pretoria, Pretoria.

Bender, T. (ed.), 1991, The university and the city: From medieval origins to the present, Oxford University Press, Oxford.

Brink, B., 2012, 'Built with Sand, Rock and Broederbond: Brian Sandrock's buildings for the University of Pretoria and the University of South Africa', South African Journal of Art History 27(3), 1-27.

City of Tshwane, 2013, viewed 14 August 2014, from http://www.tshwane.gov.za/ AboutTshwane/NewsandEvents/news/Pages/Tshepo-10000.aspx.

'Cleaning up Pretoria painful', News 24, 16 July, 2012, viewed 18 June 2015, from http://www.news24.com/SouthAfrica/Politics/Cleaning-up-Pretoria-painfulmayor-20120716.

Dreyer, E., 2013, 'Ship of fools', in Metromusings, pp. 44-55, University of Pretoria, Pretoria.

Du Toit, G., 2013, 'Staattekens 1 tot 6', in Metromusings, pp. 64-71, University of Pretoria, Pretoria.

Eksteen, F., 2013, 'The likeness in the landscape', in Metromusings, pp. 56-63, University of Pretoria, Pretoria.

Friedman, S., 1993 "The elusive "community": The dynamics of negotiated urban development', Research Report no. 28, Centre for Policy Studies, Johannesburg.

Gibson, N., 2011, Fanonian practices in South Africa: From Steve Biko to Abahlali baseMjondolo, University of KwaZulu-Natal Press, Scottsville.

Goddard, J. \& Vallance, P., 2013, The university and the city, Routledge, London.

Hamdi, N. \& Goethert, R., 1997, Action planning for cities: A guide to community practice, John Wiley \& Sons, Hoboken, NJ.

Housing Development Agency, 2012, 'Gauteng: Informal settlement status: Research Report', viewed 17 June 2015, from http://www.thehda.co.za/uploads/files/HDA Informal_settlements_status_Gauteng.pdf

Housing Development Agency, 2013, 'Gauteng: Informal settlement status: Research Report', viewed 17 June 2015, from http://www.thehda.co.za/uploads/files/HDA Gauteng_Report_Ir.pdf

Huchzermeyer, M., 2011, Cities with 'slums': From informal settlement eradication to a right in the city in Africa, UCT Press, Cape Town.

Kant, I., [1775-1780] 1997, Lectures on Ethics, transl. \& ed. P. Heath, ed. J.B. Schneewind, Cambridge University Press, Cambridge.

Kant, I., [1764] 2011, Observations on the feeling of the beautiful and sublime and other writings, ed. P. Frierson \& J. Rose, Cambridge University Press, Cambridge. 
Kistner, U., 2014, 'Heterotopograhies of a restless heritage: The west and the rest of Pretoria', Social Scientist 42(5/6), 81-102.

Lindahl, H., 2013, Fault lines of globalization, Oxford University Press, Oxford.

Losgott, K., 2013, 'Read these roads', in Metromusings, pp. 75-85, University of Pretoria, Pretoria.

Mabin, A., 2011, 'South African capital cities', in S. Bekker \& G. Therborn (eds.), Capital Cities in Africa, pp. 168-191, HSRC Press, Cape Town.

Marais, H., 2011, South Africa pushed to the limit: The political economy of change, Zed Books, London.

'Massive municipal land sale to fund housing', Pretoria East Rekord, 26 January 2015, viewed 23 June 2015, from http://rekordeast.co.za/39736/massive-municipalland-sale-to-fund-housing/

'Mixed reaction to "blackface saga"', EWN News, viewed from http://ewn co.za/2014/08/06/Blackface-public-reacts-with-outrage

Molopyane, O., 2013, 'Job creation project launched in Tshwane', The New Age, 6 September, viewed 13 August 2014, from http://www.thenewage.co.za/1065061007-53-Job_creation_project_launched_in_Tshwane

Mudzuli, K., 2015, 'Victory for plastic view residents', IOL News, 24 March, viewed 18 June 2015, from http://www.iol.co.za/news/crime-courts/victory-for-plasticview-residents-1.1836159\#.VYHLvmSeDGc

Mufamadi, S., 2001, 'Speech delivered at the Symposium on the restructuring and rebirth of the City of Tshwane', 22 November, viewed 1 September 2008, from http://www.thedplg.gov.za/index2.php?option=com_content\&do_pdf=1\&id=143

Murray, M., 2008, Taming the disorderly city: The spatial landscape of Johannesburg after Apartheid, Cornell University Press, New York.

Naicker, K., 2014, 'Pavement encounters with the homeless', UNISA News \& Media, 8 December, viewed 18 June 2015, from http://www.unisa.ac.za/news/index. php/2014/12/pavement-encounters-with-the-homeless/

Odendaal, K., 2014, circular e-mail, 14 July, kotie.odendaal@up.ac.za

Paphitis, S. \& Tabensky, P., 2014, 'Get out of your armchairs, academics', Mail \& Guardian (Getting Ahead Supplement), 05 July, viewed 13 August 2014, from http://mg.co.za/article/2014-07-05-get-out-of-your-armchairs-academics

'Pathways out of homelessness: Tshwane Homeless Summit', UP News, 12 May 2015, viewed 17 June 2015, from http://www.up.ac.za/en/news/post_2079167pathways-out-of-homelessness-tshwane-homeless-summit

Ramokgopa, K., 2015, 'State of the Capital Address', 14th May, viewed 24 June 2015, from http://www.tshwane.gov.za/Documents/SOCA_2015_EM_autoqueue_final_ version.pdf

Rancière, J., [1995] 1999, Disagreement, politics and philosophy, transl. J. Rose, University of Minnesota Press, Minneapolis, MN

Selmeczi, A., 2011, 'From shack to the Constitutional Court: The litigious disruption of governing global cities', Utrecht Law Review 7(2), 60-76.
South Africa, 1996, 'Constitution of the Republic of South Africa, no. 108 of 1996', viewed 2 October 2015, from http://www.gov.za/sites/www.gov.za/files/images/ a108-96.pdf

South Africa, 1998, 'Prevention of illegal eviction from and unlawful occupation of Land Act 19 of 1998', viewed 02 October 2015, from http://www.saflii.org/za/ legis/consol_act/poiefauoola1998627/

Tsunke, S., 2013, 'Capital cities project launched in conjunction with City of Tshwane', 10 October, viewed 11 August 2014, from http://web.up.ac.za/default.asp?ipkCat egory|D $=8641$ \&article $\mid D=18361$

University of Pretoria, n.d., 'Administration building', viewed 14 June 2011, from https://repository.up.ac.za/upspace/handle/2263/6558

University of Pretoria, Department of Architecture, 2015, 'Human settlements and urbanism', Course outline for RFP721/2/3: BArch (Hons) Pretoria.

University of Pretoria, Faculty of Economic and Management Sciences, 2011, viewed 14 August 2014, from http://web.up.ac.za/default.asp?ipkCategorylD=837; changed in 2015 to following link: http://www.up.ac.za/en/faculty-of-economicchanged in 2015 to following link: http://www.up.ac.za/en/faculty-of
and-management-sciences/article/15662/community-engagement

University of Pretoria, University of South Africa, City of Tshwane, Tshwane Homelessness Forum, 2015, 'Pathways out of homelessness in the City of Tshwane: Research and strategy development for the Homeless Summit 2015', viewed 17 June 2015, from https://tshwanehomelessresearch.files.wordpress. com/2015/01/homelesssummit-researchplan.pdf

Van der Klashorst, E. \& de Villiers, C., 2013, 'Pretoria: Past, present, precarious', in Metromusings, pp. 24-37, University of Pretoria, Pretoria.

Van der Merwe, L., 2013, 'Urban ontologies', in Metromusings, pp. 86-93, University of Pretoria, Pretoria.

Van der Walt, A., 2009, 'Reliance and denial in legal histories', PULP Fictions, Pretoria University Law Press, Pretoria, viewed 17 June 2015, from http://www.pulp.up.ac. za/pdf/2009_05/2009_05.pdf

Van Rooyen, M., 2013, 'Concrete identities', in Metromusings, pp. 98-105, University of Pretoria, Pretoria.

Van Zuydam, L., 2013, 'Tshwane has 10000 jobs for residents', IOL News, 26 July, viewed 13 August 2014, from http://www.iol.co.za/pretoria-news/tshwane-hasviewed 13 August 2014, from http://www.iol.co.za/p
10-000-jobs-for-residents-1.1553031\#.U-tGsYCSyoU

Von Holdt, K., 2013, 'South Africa: The transition to violent democracy', Review of African Political Economy 40(138), 589-604. http://dx.doi.org/10.1080/0305624 4.2013 .854040

Wikipedia, n.d., Administration building ("Die skip") on its Hatfield campus, viewed from https://upload.wikimedia.org/wikipedia/commons/thumb/d/df/Die_skip_ University_of_pretoria.JPG/1920px-Die_skip_University_of_pretoria.JPG

Wikipedia, n.d., 'Voortrekker Monument', viewed from https://en.wikipedia.org/wiki/ Voortrekker_Monument\#/media/File:Voortrekker_Monument.jpg

Wood, A.W., 1999, Kant's ethical thought, Cambridge University Press, Cambridge. 